\title{
Danske studieledere står ved en kritisk skillevej
}

\author{
Thomas Harboe, centerleder, ph.d., ved Pædagogisk Center Samfundsviden- \\ skab, Københavns Universitet
}

\section{Reviewet artikel}

Denne artikel sætter fokus på studielederne ved de danske universiteter. Artiklen tager udgangspunkt i de seneste 20-30 års universitetsreformer, hvor man finder et gennemgående ønske om, at studielederne - lige som den øvrige ledelse ved universiteterne - skal "styrkes" på forskellig vis. De studieledere, der blev interviewet ifbm. ph.d.-projektet (Harboe 2013), er imidlertid ikke de veldefinerede ledere, som universitetsreformerne angiveligt lægger op til. Tværtimod tegnes et billede af studieledere, der står $i$ en mere indirekte og forhandlingspræget kobling til deres omgivelser. Studielederne er på den anden side ikke i tvivl om, at universiteterne i stigende grad er domineret af NPM-reformer. Konsekvensen er, at studielederne står ved en kritisk skillevej mellem traditionel kollegial ledelseskultur og en NPMinspireret virksomhedspræget ledelseskultur.

\begin{abstract}
Universiteternes ledelseskultur er under forandring, ligesom tilfældet er for ledelseskulturen i resten af den offentlige sektor. Universiteterne, der ellers historisk set har været præget af en flad, kollegial ledelsestilgang, bliver reformeret og står i dag med en ny form for generiske ledere, HR-afdelinger og ledelsesudviklingsprogrammer. Samtidigt bliver hierarkierne styrket og magten centreret omkring topledelsen analogt med, at de kollegiale organer ( $f x$ akademisk råd) har fået reduceret deres indflydelse betydeligt. Alt sammen argumenteret ved at universiteter har brug for store reformer og, at det er lederne, der står med ledelsesansvaret for at reformerne lykkes.
\end{abstract}

Faglitteraturen har længe skrevet om denne udvikling (Dopson \& McNay, 1996; Dahler-Larsen \& Gleerup, 2001; Gleerup, 2007; Klausen, 2001; Norman Andersen, 2007; Pedersen et al., 2008; Moos, 2008; Wright \& Ørberg, 2008; Graversen m.fl., 2009, Kristensen et al., 2011). Især skrives der meget om en global reformbølge under betegnelser som neo-liberal og/eller New Public Management (NPM), der vel at mærke ikke skal forstås om ét samlet teorikompleks, men snarere som en samlebetegnelse for en række reformtendenser med en hovedantagelse om, at decentralisering, markedskræfter og nye hierarkiske ledelsesformer i den offentlige sektor vil føre til bedre omkostningsstyring, højere effektivitet og bedre kvalitet uden væsentlige negative sideeffekter.

Jeg vil i denne artikel argumentere for, at studielederne ved danske universiteter som følge af denne udvikling - i de seneste fire-fem år har stået ved en kritisk skille- 
vej. Det er en skillevej, der er forbundet med en signifikant forandret ledelsessituation. Samtidigt er det endnu en meget uafklaret situation, hvor traditionelle handlemuligheder lukkes, uden at det står klart, hvordan de nye handlemuligheder vil blive.

\section{Metode}

Artiklen bygger på 11 semistrukturerede dybdegående kvalitative interviews med danske studieledere fra 5 ud af 8 universiteter kombineret med litteraturstudier og dokumentariske studier, der er gennemført i forbindelse med min ph.d.-afhandling (Harboe, 2012). Det er ikke et studie af, hvordan studieledelse fungerer uafhængigt af tid og sted, men snarere en diskussion af, hvordan udvalgte danske studieledere håndterer bestemte ledelsestilgange på et givet tidspunkt og inden for givne institutionelle rammer.

\section{Kritiske skilleveje}

Institutioners historik kan have afgørende betydning for, hvordan forskellige reformer, strategier og ledelsesbeslutninger formuleres og udvikles. Inden for historisk institutionel teori (Nielsen et al., 2005; Normann Andersen, 2005; Pedersen et al., 2008) taler man om, at forandringer er sporafhængige ('path dependence'), dvs. at udvikling sker på en måde, der er begrænset af tidligere spor, som i praksis ofte fungerer som barrierer for forandringer, selv når mere effektive og bedre løsninger menes at være til stede. Både problem- og løsningsdefinitioner er derved sporafhængige.

Udfordringen for historisk institutionel teori er at forklare, hvordan nye tanker og udvikling opstår og integreres. Hvis institutionel udvikling er sporafhængig, bliver nytænkning noget, der enten må komme udefra eller noget, der sker inkrementelt. Der er med andre ord en indbygget konservativ bias i historisk institutionel teori, der besværliggør en forståelse af drivkræfterne i de dynamiske processer, der findes i enhver institution og for at kompensere for dette, argumenterer teoretikere, at institutionelle forandringer undertiden kan tage form af at være en kritisk skillevej ('critical junctures'), hvor der skabes nye spor, der følges i de efterfølgende år.

Den kausale logik bag en sådan kritisk skillevej er, at den forandring, der følger af skillevejen, skal være af signifikant betydning og altså sætte nye varige spor. Den kritiske skillevej udelukker alternative valg og fører til en ny selvforstærkende og sporafhængig proces. De muligheder og strukturer, der før skillevejen var dominerende, vil med andre ord typisk være forsvundet, omformet eller på anden vis erstattet efter skillevejen. Samtidig er situationen ved selve skillevejen kendetegnet ved stor uklarhed og kontingens, for selvom skillevejen er kendetegnet ved en række valg, er de nye og alternative handlemuligheder typisk endnu ikke defineret eller på anden måde specielt klare.

\section{Danske studieledere}

Et eksempel på en kritisk skillevej var introduktionen af studielederne som ny ledelseskategori tilbage i 1993. Før 1993 skulle alle væsentlige beslutninger vedrørende 
studierne formelt besluttes i forskellige kollegiale råd og studienævn. Det var en organisationsform, der ofte beskrives som organiseret anarki eller som et løst koblet system (Weick, 1976), og som givetvis fungerede hensigtsmæssigt flere steder, men som også var genstand for voldsom debat op gennem 1970'erne og 1980'erne. Især politikerne anklagede universiteterne for at være præget af tunge, langsommelige beslutningsprocesser, hvor alle uanset stillingsmæssigt tilhørsforhold skulle høres (Petersen. 1997; Graversen et al., 2009; Kristensen et al., 2011).

Der var således fra politisk side en klar ambition allerede i starten af 1990'erne om at gøre universitetsledelsen mere veldefineret og beslutningsdygtig og samtidig reducere de styrende, demokratiske organers formelle kompetence. Dette skulle ske gennem en klarere placering af ledelsesansvaret hos individuelle og identificerbare ledere med selvstændig kompetence til at træffe beslutninger. Universitetsloven fra 1993 indeholdt derfor en ændret ledelsesstruktur, hvor der blev lagt mere vægt på det personlige beslutningsansvar på alle niveauer (rektor, dekaner, institut- og studieledere).

Studienævnene, der formelt blev introduceret ved vedtagelsen af universitetsstyrelsesloven i 1970, fortsatte også efter 1993, men med den ikke uvæsentlige ændring, at studienævnsformændene blev til studieledere (UL1993, § 8, Stk. 7). Der står meget lidt om studieledernes funktion og rolle i selve UL1993, men i lovforslaget opridses en række forventninger til studielederen:

"Med oprettelse af studielederfunktionen er der samtidig placeret et direkte ansvar for den undervisning, som ikke fungerer. Hvis lærerne ikke opfylder kravene, har de studerende nu fået en personligt ansvarlig, de kan holde sig til." (Lovforslag 1992/1 LSF 75, almindelige bemærkninger).

Det interessante ved studielederne er, at de på trods af denne universitetspolitiske opmærksomhed aldrig er blevet tildelt formel ledelseskompetence. De er lokalt forankrede funktionsledere uden ledelsesansvar for personale eller økonomi. Dertil kommer, at deres ledelsessituation fra starten har været kendetegnet ved, at en lang række aktører i og uden for basisorganisationen arbejder ind over studieledernes arbejdsfelter. Studienævn, prodekaner, institutledere, administrative medarbejdere har alle beslutningskompetencer og arbejdsfunktioner, der ligger på kanten af eller direkte går ind over, hvad man forestiller sig, en studieleder arbejder med. Studielederne forventes altså at lede nogen (underviserne), der ledes af andre (institutlederne, studienævn m.fl.), og studielederne er som sådan bemærkelsesværdigt underdefineret i juridisk og formel forstand.

Trods dette kan man spore generelt stigende forventninger rettet mod studielederne siden 1993. Studielederne skal nu også kunne agere fornuftigt i forhold til udviklingskontrakter, lovbekendtgørelser, økonomiske bonusordninger mv. Noget der kræver, at studielederne har tilegnet sig viden om, hvordan universiteterne er organiseret lokalt og i forhold til omverdenen. 
Konsekvensen er, at vi i dag, 20 år efter at studielederne blev introduceret som ledelseskategori, står ved en ny kritisk skillevej. Studielederne er stadig ledere uden mandat, men der arbejdes lokalt på flere danske universiteter med reformer af studieledelsesstrukturen ${ }^{1}$, og at dømme ud fra disse reformer kunne fremtiden for studielederposten pege i retning af en mere langsigtet proaktiv udviklingsledelse, eller nærmere bestemt strategisk ledelse. ${ }^{2}$

Midlet til at opnå denne målsætning om mere strategisk, handlekraftig og synlig ledelse på universiteterne er så angiveligt en mere veldefineret og hierarkisk ledelsesstruktur. Det fremgår fx af en aktuel rapport fra Uddannelses- og Forskningsministeriet:

"På alle uddannelsesinstitutioner bør ansvaret og de beføjelser, der vedrører den enkelte uddannelse, ligge entydigt hos én person, som er tæt på uddannelsen og den daglige undervisning. Det gælder $\mathrm{fx}$ i forhold til at disponere de samlede ressourcer til uddannelsen, valg af undervisere mv. Også udvikling af uddannelsens pædagogiske form, faglige indhold og undervisernes pædagogiske kompetencer bør være et anliggende for denne person, som derfor også bør have en reel indflydelse på ansættelser, aflønning mv., selv om det ikke er vedkommendes direkte ansvar. Det er vigtigt, at den leder, der får delegeret ansvaret for den enkelte uddannelse, også kan holdes ansvarlig for uddannelsens udvikling. (Udvalg for Kvalitet og Relevans i de Videregående Uddannelser 2015, s. 42f)."

\section{Traditionel kollegial studieledelse}

De studieledere, der er interviewet i forbindelse med mit ph.d.-projekt (Harboe, 2012), fortæller i kontrast hertil om en hverdag, der langt fra er så veldefineret, som man måske kunne ønske sig, men som tværtimod ofte er præget af tilfældigheder og situationer med mange modsatrettede interesser. Denne uklare ledelsessituation opleves dog ikke nødvendigvis som et problem. Når man spørger studielederne selv,

\footnotetext{
${ }^{1}$ Se eksempelvis: Aarhus Universitet (2011): Den faglige udviklingsproces. Aalborg Universitet (2010): Statusnotat vedr. etablering af skoler på fakulteterne. (Internt notat). Syddansk Universitet (2009): Delpolitik for: Studieledelse og studieadministration. Syddansk Universitet, (2010): Studieledelse. Visioner, roller, opgaver m.m. Det Samfundsvidenskabelige Fakultet.

${ }^{2}$ Definitionen af strategisk ledelse er netop en ledelse, der arbejder med planlægning og organisationen som helhed, og traditionelt opfattes strategisk ledelse inden for det offentlige derfor som noget, der er forbeholdt politikerne eller topledelser (Bakke \& Fivelsdal, 2010). Strategisk ledelse involverer imidlertid i stigende grad også lokale ledere på lavere ledelsesniveauer. Strategisk ledelse har været på dagsordenen inden for det offentlige siden starten af 1990'erne, og her har de lokale ledere været kritiseret for at være for driftsorienterede, og der har været et ønske om, at lederne skulle være mere opmærksomme på de overordnede forhold (Klausen, 2001). Det er i dette lys, at de seneste universitetsreformer skal tolkes: Studielederne skal ikke fortabe sig i hverdagens små problemer men skal tværtimod skabe udvikling gennem en mere overordnet, distanceret og fremtidsorienteret ledelse. Aktuel faglitteratur problematiserer denne pointe, $\mathrm{fx}$ argumenteres der for, at ledelse ofte handler om at se udviklingsmuligheder i hverdagens driftsprægede arbejdsopgaver (fx Juelskjær, 2012).
} 
ser de det som et arbejdsvilkår, de lever med, og nogle trives oven i købet ganske godt med en vis grad af uforudsigelighed og uorden.

Studielederne ved godt selv, at de har en stor udfordring med at definere deres egen ledelsesstatus:

"Altså, det er jo egentlig en mærkelig titel, studieleder, fordi man leder jo stort set ikke nogen. Du får ikke nogen ledelseskompetencer. Du har ikke nogen formel ledelse. Til gengæld er der meget uformel ledelse eller politisk ledelse, om man vil. Jeg synes, det er et meget misvisende begreb med studieleder. Ja, jeg har ikke noget bedre. Måske er jeg mere en studieudvikler eller sådan noget." (SL06).

Det er det klassiske kollegiale ledelsesideal, der kommer frem i lyset, når studielederne på denne måde fortæller, at de ikke ser sig selv som ledere. Det er et billede af reflekterede, men også meget tøvende og tilbageholdende kollegiale studieledere, der ikke har påtaget sig studielederhvervet ud fra ønsket om en ledelseskarriere, men mere som et mere eller mindre selvvalgt afbræk i deres forskerkarriere. Mange af de studieledere, jeg interviewede, pointerede da også, at de kun er studieledere for en kort periode.

Set i dette lys er det interessant, at flere studieledere alligevel taler om, at de har særlige funktioner og muligheder, som $\mathrm{fx}$ institutlederen antages ikke at have. Studielederne er ganske vist tydeligt begrænset af, at institutlederen er deres nærmeste formelle leder og arbejdsgiver, og at studielederne ikke kan "sætte trumf" bag deres ord overfor underviserne. Denne begrænsning er imidlertid også deres mulighed i og med, at studielederen får en udenforstående ledelsesposition, hvor studielederen både kan trække på en privilegeret merviden om studerende og undervisningen, og samtidigt ikke være en del af den hierarkiske magtrelation, der eksisterer mellem institutlederen og underviserne. Studieledere kan netop i kraft af ikke at have den hierarkiske indplacering løfte komplicerede uddannelsespolitiske ledelsesopgaver ved i stedet at lede mere indirekte med "venlige samtaler" og "forespørgsler". Det er ikke straf og belønning, der løfter ledelsesopgaverne her, men derimod forhandling.

Forhandling er i det hele taget det mest gennemgående tema blandt de studieledere, jeg har interviewet, og til dette knytter sig også en understregning af, hvor vigtigt der er, at studielederne er anerkendende og lydhøre over for undervisernes situation. Studieledernes evne til at samtale spiller her en afgørende rolle:

"Jeg går ikke ud og siger, 'Nu skal I gøre det på den her måde', men jeg siger, 'Hvordan kan vi gøre det bedre?' Og det vil folk jo gerne." (SL06).

Selv i de tilfælde, hvor forhandling synes at komme til kort, fortsætter studielederne med at forhandle, primært fordi det er deres eneste mulighed. En studieleder fortalte om, hvordan hun har været i dialog med en af instituttets ældre professorer om eksamensformerne: 
"Så er der nogle ret autonome professorer, hvor det kan være ret svært at få dem til at ændre eksamensform. Vi varierer meget eksamensformerne på overbygningen, det er meget vigtigt. En tredjedel af dem er med skriftlig hjemmeopgave, fordi der et krav om, at de studerende skal have mindst tre af den slags eksaminer på overbygningen, men der skal også være nogle mundtlige eksaminer. Der skal være variation i det. Og så er der en professor her, der gang på gang kun laver seminarer med skriftlige hjemmeopgaver. Hvor jeg en gang før simpelthen måtte opgive, fordi han sagde: 'Det er for sent at lave om. Det kan jeg ikke'. Men den her gang, der får han bare ikke lov, det har jeg også sagt til afdelingslederen. Men det kan jo godt være svært, hvis det er nogle med mange års erfaring, og de har aldrig oplevet en studieleder sige sådan noget til sig før. Men det der får han simpelthen ikke lov til. Han får ikke lov til at lave to seminarer med hjemmeopgaver, så må han droppe det ene seminar. [...] Nu må vi se hvad der kommer ud af det. Forskere er jo tit nogle stærke egoer." (SL10).

Det kræver en stærk og beslutningsdygtig studieleder at komme videre herfra, og det er tænkeligt, at andre studieledere i lignende situationer ville resignere og undlade at følge op på sådanne konfrontationer. I dette tilfælde valgte studielederen, at lade situationen passere sidste år men besluttede samtidigt, at det ikke skulle gentage sig igen i år. Det er klart, at ovennævnte studieleder har en stærk sag i og med, hendes institut har vedtaget en politik, som omtalte professor ikke respekterer, og man kan argumentere for, at studielederne ikke ville være meget ledere, hvis de ikke holder fast i policybeslutninger af denne karakter. Eksempler med studieledere, der træder i karakter på denne direkte måde, finder man da også primært i situationer, hvor der er en klar politik eller lov, som studielederne forventes at forvalte. Man kan sige, at der, hvor studielederne er mindst forhandlende og mest direkte i deres ledelsesstil, er situationer, hvor studieledelse får karakter af at være administrativ ledelse, dvs. ledelse af drift, regler og policy.

Ovenstående studieleder har besluttet at stå relativt fast på sin beslutning. Alligevel er der stadig en udpræget pragmatisme i hendes historie. Det er ikke en studieleder, der for alvor "banker i bordet" og forlanger, at omgivelserne skal rette ind. Tværtimod er der stadig en vilje til at indgå kompromisser: "Nu må vi se hvad der kommer ud af det", siger hun til sidst. Denne kompromisvillighed er udbredt hos alle de studieledere, som jeg har interviewet. Det handler om at få hverdagen til at fungere. Da studielederne ikke står i en ledelsessituation, hvor han eller hun kan insisterer på, at omverdenen følger hans eller hendes anvisninger, må studielederne forsøge at forhandle sig frem, og selv i de tilfælde, hvor forhandling tilsyneladende ikke er nok, er en fortsat forhandling stadig eneste mulighed for studielederen.

Set i dette lys er der ikke meget der tyder på, at danske studieledere har taget skridtet væk fra den traditionelle kollegiale ledelsestilgang og i retning af en mere NPMinspireret, virksomhedspræget ledelsestilgang. Det er i alle fald tydeligt, at studielederne ikke opfatter sig selv som ledere med et stærkt og veldefineret mandat, og at 
de synes at være påfaldende bevidste om, at de har meget lidt formel beslutningskompetence, og at de konstant risikerer at blive underkendt af andre ledere. De er med andre ord ikke den slags let identificerbare, handlekraftige og personligt ansvarlige "ledere med stort L", som universitetsreformerne i de seneste 20 år har efterlyst. Tværtimod tegnes et billede af studieledere, der står i en mere indirekte og forhandlingspræget kobling til deres omgivelser.

\section{Nye tider}

Studielederne fortæller imidlertid også, at der er kommet nye tider inden for studieledelse, og at deres traditionelle kollegiale ledelsestilgang er under pres. Det er en udvikling, der kommer fra alle kanter af organisationen, og som presser studielederne til at udvikle nye måder at agere på.

Gennemgående er studielederne ikke i tvivl om, at de formelle strukturer er blevet mere dominerende i de seneste år. Flere studieledere fortæller om, hvordan de har oplevet, at hierarkiske kommandoveje er blevet etableret i relationer, hvor der ikke var tilsvarende kommandoveje før, og det er vel at mærke en formalisering af kommandovejene, der også inkluderer studielederne, omend på en mere indirekte måde. En studieleder fortæller, hvordan VIP' erne opfatter hende som en del af ledelsen samtidig med, at hun selv oplever, at hun står uden indflydelse.

"Altså, studielederkurset gjorde jo meget ud af, at man skal have en vision. Men sådan havde jeg det egentlig ikke. Jeg havde nok mere tænkt, at jeg bare skulle køre butikken. Jeg opfatter mig selv som leder, men på et sted, hvor folk også er nogle meget stærke individer. Der er mange, som siger til mig, 'Du er jo en del af ledelsen, så sådan og sådan og sådan.' Og det er jo rigtig nok. Men der er også nogle ting, jeg ikke har så stor indflydelse på. Fx lige nu har alle overskud i instituttets undervisningsregnskab, så derfor har vores institutleder aflyst vores "ottende frisemester", så at folk kan få mulighed for at få det der overskud ned, for ellers kan man ikke få folk til at undervise. Men det var ikke min beslutning, det var en beslutning i forhold til, at institutlederen havde siddet og kigget på budgettet. Det gode er, at nu har jeg haft for mange, der vil undervise. De to sidste semestre har jeg skullet gå rundt og bede folk om at undervise. Og det er klart, at der har han lavet en ændring, som virkelig hjælper mig, fordi det bliver nemmere at få folk til at undervise. Men når nu mine kollegaer siger: 'Nu når I har taget den her beslutning', er det jo ikke helt rigtigt, fordi det har jeg faktisk ikke været med til at beslutte. Men det er jo rigtig nok, at det er ledelsens beslutning, selvom det jo ikke rigtig er min." (SL10).

Ovenstående citat giver et billede af, hvordan studielederne får sværere og sværere ved at trække på deres kollegialitet ("jeg er jo bare en af jer"), når de leder underviserne. Sammenhængen synes at være, at når studieledernes ledelsesstatus kommer tydeligere i forgrunden, bliver den kollegiale ledelsestilgang tilsvarende sværere at praktisere. 
Fordelen ved formelle kommandoveje er i sagens natur en klarere arbejdsdeling mellem ledelse og medarbejdere, og mellem medarbejderne indbyrdes. Samme arbejdsdeling risikerer dog samtidigt at blive meget ufleksibel og bureaukratisk. En studieleder, der før samarbejdede med en velfungerende og fysisk tæt placeret studieadministration, men som nu er flyttet længere væk fra studieadministrationen, er fx frustreret over at være direkte afkoblet budgetplanlægningen:

"Vores nuværende administrative leder siger, han ved, hvad der står i budgettet og kender regnskabet, men jeg kan ikke få noget at vide om det. Det er noget af det jeg synes er kritisk ved den nye universitetslov, det er, at mange af de ting er skjult. Tidligere fik jeg altid regnskabsudskrifter på mine konti, men dem fik jeg lige pludselig ikke mere. Og jeg ved ikke hvorfor, jeg har aldrig fået noget at vide. Det er fandens svært at planlægge noget som helst og hvis jeg skal bruge penge til nye lærerkræfter eller lave om på tingene, så aner jeg ikke en gang hvor mange penge jeg har, så til sidst brugte jeg bare penge uden at vide, om jeg havde det. Og det er den form for uansvarlighed, som jeg ikke startede med som studieleder, men som jeg er endt med. Og det synes jeg er lidt træls, for at sige det rent ud." (SL11).

Ifølge studielederen er der centrale dele af det, som han før oplevede som en naturlig del af sit studielederansvar, der er henlagt til studieadministrationen. Han oplever oven i købet, at det er "skjult" for ham. Andre studieledere havde lignede historier, fx fortalte en studieleder, hvordan det studieadministrative personale havde henvendt sig med ønsket om, at studielederen fremover ikke måtte mødes med menige studerende, da det skaber forvirring i den almindelige sagsbehandling.

Hvorvidt denne udvikling opleves som en frustrerende afkobling (at være kørt ud på et sidespor) eller en fornuftig arbejdsdeling mellem studieadministrationen og studielederen, afhænger af hvem, der ser på situationen. Men det er en naturlig følge af en hierarkisk organisation, at der er noget, der er "skjult" eller på anden vis opdelt. Regnskaberne er fx mere eller mindre "skjulte" som resultat af en ny arbejdsdeling mellem, i ovennævnte tilfælde, den administrative leder og studielederen.

De fleste studieledere, jeg har interviewet, er påfaldende kritiske over for denne udvikling, og de peger på, at udviklingen ikke mindst har negativ betydning for deres handlemuligheder inden for uddannelsesdesign og -udvikling. En studieleder oplever fx, hvordan nye NPM-inspirerede uddannelsesreformer om bl.a. kortere studietider har en tendens til at dræbe ellers fornuftige initiativer:

"Jeg synes, at meget af det, der kommer fra ministeriet, er anti-pædagogisk. For man sidder netop og bruger så meget krudt på at få de studerende hurtigt og effektivt igennem, og det vil sige, at vi skal have effektive undervisningsformer, og det vil sige, at det der med at sidde og lege med tingene, det bliver der sgu ikke mere tid til. Nu laver man kun det, der er nødvendigt, fordi det hele bliver detailstyret ovenfra, og så kan man lige så godt lade være med 
pædagogisk udvikling, fordi det ikke kan betale sig. Man risikerer bare, at man har lavet en masse sjove og spændende undervisningsformer, og så får man bare hug og at vide, at det ikke kan lade sig gøre, og så kan man lige så godt lade være, for så har man spildt sin tid. I dag kunne jeg godt have lyst til at være med til at udvikle en ny uddannelse. Men det gider jeg ikke. Altså i dag vil jeg gætte på, at man ikke kan starte en ny uddannelse, uden at man har institutleder og dekan til ikke bare at sige, det er en god plan, men til at gå helhjertet ind for det. Det gjorde jeg engang faktisk. Jeg startede en uddannelse helt fra scratch uden opbakning og jeg skaffede opbakning hen ad vejen. I dag er det slet ikke den der bottom-up proces. I dag sidder du og ser på, hvordan behovet er forskellige steder, og så siger man: 'Udvikl den uddannelse!'. Og det er efter min mening hæmmende." (SL11).

Det er tænkeligt, at studielederne tager fejl i deres skepsis over for NPM-inspirerede reformer, og at uddannelsesudvikling på flere områder reelt er blevet både lettere og mere effektiv med en mere veldefineret organisation, der bedre kan arbejde sammen om de ofte meget komplicerede organisatoriske processer. Mine undersøgelser kan hverken be- eller afkræfte dette, men det har heller ikke været en pointe for mig. Min pointe er derimod at afdække, hvordan studieledere oplever, at der er nye tider inden for studieledelse, og at de føler sig presset af denne udvikling. Det er den kritiske skillevej mellem forskellige ledelsestilgange, som studielederne mærker her.

\section{Konkurrerende ledelsestilgange}

Der er lang vej fra de kollegiale studieledere, der dagligt løber spidsrod mellem studerende, undervisere/forskere, studienævn, institutleder, fakultetsledelse og studieadministration i et forsøg på at få de mange ender til at mødes til den form for stærke super-studieledere, som de seneste universitetsreformer lægger op til, hvor det handler om, at studielederne skal tænke langsigtet og i helheder, og hvor midlet til at nå dette er at gøre studieledelsen mere hierarkisk veldefineret og studielederne mere professionelle og strategisk tænkende. Normalt vil man også opfatte traditionel kollegial ledelsestilgang og NPM-inspireret virksomhedspræget ledelsestilgang som hinandens modsætninger, hvor førstnævnte er mere forhandlende og bottom-up af natur og sidstnævnte er mere strategisk og top-down af natur. Det er svært at forestille sig kombinationer eller overlap mellem disse.

En række spørgsmål trænger sig dog på i denne forbindelse: Kan kombinationer af forskellige ledelsestilgange eksistere på samme tid i samme organisation? Kan kollegiale og NPM-inspirerede ledelsestilgange overhovedet eksistere i deres rene form? Eller er de forskellige ledelsestilgange tværtimod afhængige af hinanden i den forstand, at de spejler sig i hinanden og at de nuanceres og udbygges gennem kritik af hinanden? 
Pointen er, at de tilgange, der ledes ud fra, ikke er neutrale men har en afgørende indflydelse på, hvordan medarbejdere og organisation kan forstås og, hvad der er muligt. Andersen \& Thygesen beskriver denne pointe således:

"Styringsværktøjer er aldrig uskyldige. De enkelte styringsværktøjer rummer meget forskellige strategiske og udviklingsmæssige muligheder. Afhængigt af hvilket værktøj, man styrer efter, træder organisationen, dens omverden, dens medarbejdere, dens fremtid, dens styrker og dens svagheder forskelligt frem og dermed bliver ens valgmuligheder som leder forskellige." (Andersen \& Thygesen 2007).

Andersen \& Thygesens argument er, at styringsværktøjer er iagttagelsesværktøjer, der tillader en at se samtidig med, at man ikke ser det, styringsværktøjerne ikke gør synligt, og at man ikke ser, at man ikke ser det. Det er den velkendte historie om, at når man står med en hammer, består verden af søm. Den, der står med hammeren, kan bestemme, hvad hammeren skal slå på, og hvordan hammeren skal slå, men fokus er rettet mod at finde søm til hammeren. På tilsvarende måde indsnævrer ledelsestilgange både ledernes og medarbejdernes fokus og handlerum gennem, hvad der stilles skarpt på, og det er i tillæg ikke muligt at fastslå, om den ene ledelsestilgang er bedre end den anden, fordi de hver især styrer, hvad man får øje på og, hvad man ikke får øje på.

Der er ikke langt herfra til at tale om en egentlig konkurrence mellem forskellige ledelsestilgange, hvor ledelsestilgangene i deres daglige virke risikerer at neutralisere eller direkte modarbejde hinanden. I studieledernes tilfælde kunne en sådan konkurrence findes mellem hierarki og forhandling; mellem strategi og hverdag, mellem løst og fast koblede systemer, og mellem demokrati og "leadership". Fx er det tænkeligt, at den nye NPM-inspirerede strategiske ledelsestilgang har en indbygget tendens til at "kvæle" den traditionelle kollegiale ledelsestilgang, fordi den kollegiale ledelsestilgang bygger på tillidsrelationer, som kun kan fungere, hvis der ikke er evig risiko for at blive "kuppet" af en strategi. Modsat er det tænkeligt at tværgående uddannelsesstrategier modarbejdes af kollegiale studieledere, der har svært ved at se ud over basisorganisationens lokale horisont.

\section{Konklusion}

Artiklen har skitseret hvordan studielederne står ved en kritisk skillevej mellem traditionel kollegial ledelsestilgang og en NPM-inspireret virksomhedspræget ledelsestilgang. Der er utvivlsomt styrker og svagheder i begge former for ledelsestilgange, men det har dog ikke været målet for denne artikel at diskutere præcist hvordan. Hvad artiklen derimod har haft til mål at vise er, at der er tale om en kritisk skillevej, hvor der er meget på spil for studielederne, og at det pres, som studielederne oplever, sandsynliggør, at universiteterne i længden ikke kan rumme så forskellige ledelsestilgange samtidigt. Studielederne synes med andre ord at kunne se frem mod nye tider, der på mange måder adskiller sig fundamentalt fra den ledelseskultur, de kender i dag. 
Thomas Harboe har arbejdet inden for det universitetspædagogiske felt siden midten af 1990erne. Han er til daglig leder for Pædagogisk Center Samfundsvidenskab, Københavns Universitet (KU) og har gennem årene skrevet bøger og artikler inden for studieteknik, vejledningspædagogik, metode m.m. I foräret 2013 forsvarede han en ph.d.afhandling om studieledelse ved danske universiteter. Han har fortsat dette fokus på studieledelse og fungerer i dag også som projektleder for KU's universitetspædagogiske program rettet mod studieledere.

\section{Litteratur}

Åkerstrøm Andersen, N. \& Thygesen, N. T. (2007). Styring af styringsværktøjer. I C. Greve (red.), Offentlig ledelse og styring. København: Djøf/Jurist- og Økonomforbundet. s. 65-74.

Bakka, J. F. \& Fivelsdal, E. (2010). Organisationsteori. Struktur, kultur, processer. 5. udg. København: DJøF forlag

Dahler-Larsen, P. \& Gleerup, J. (2001). Mellem strategier og videnstrømme. Rapport fra projektet "Vurdering af personalepolitiske instrumenter til omstilling og kvalitetsudvikling på universitets-undervisningsområdet". Omstillingsfonden, sCCK-rapport.

Dopson, S. \& McNay, I. (1996). Organizational culture. In D. Warner \& D. Palfreyman (red.), Higher Educational Management. The Key Elements. Buckingham: Open University Press.

Gleerup, J. (2007). Pædagogisk ledelse - organisatorisk udvikling via strategisk conversation og licens til kritik. In A. v. Oettingen \& F. Wiedemann (red.): Mellem teori og praksis. Odense: Syddansk Universitetsforlag.

Graversen, E. m.fl. (2009). Universitetsledelse. København: DJøF forlag.

Harboe, T. (2013). Subtil ledelse i en ny og mere insisterende form, en kvalitativ studie af studieledere ved danske universiteter. Syddansk Universitet. Ph.d.afhandling.

Juelskjær, M. m.fl. (red.) (2011). Ledelse af uddannelse. At lede det potentielle. Frederiksberg: Samfundslitteratur.

Klausen, K. K. (2001). Skulle det være noget særligt? Organisation og ledelse i det offentlige. København: Børsens Forlag.

Kristensen, J. E., Nørreklit, H. \& Raffnsøe-Møller, M. (red) (2011). University Performance Management. København: DృøF Publishing

Moos, L. (2008). A general context for new social technologies. In Nordisk pedagogik, 29(1), s. 79-92.

Nielsen, K. (red.). Institutionel teori. En tværfaglig introduktion. Roskilde: Roskilde Universitetsforlag.

Pedersen, D., Greve, C. \& Højlund, H. (2008). Genopfindelsen af den offentlige sektor. Ledelsesudfordringer i reformernes tegn. København: Børsens Forlag.

Petersen, N. (1997). Autonomy and professionalism - Danish higher education and the problems of state interference. In K. D. Wolff (red.): Autonomy and External Control - The University in Search of the Golden Mean. München: Ludicium Verlag $\mathrm{GmbH}$.

Udvalg for Kvalitet og Relevans i de Videregående Uddannelser (2015). Nye veje og 
høje mål. Kvalitetsudvalgets samlede forslag til reform af de videregående uddanne/ser. Se: http://ufm.dk/publikationer/2015/nye-veje-og-hoje-mal/nyeveje-og-hoje-mal-kvalitetsudvalgets-samlede-forslag-til-reform-af-devideregaende-uddannelser.pdf

Universitetsloven. Lovforslag 1992/1 LSF 75, almindelige bemærkninger

Universitetsloven. Lovbekendtgørelse nr 334 af 27/05/1993 (offentliggørelsesdato: 04/06/1993) Uddannelses- og Forskningsministeriet. Se: https://www.retsinformation.dk/Forms/R0710.aspx?id=74747

Weick, K. (1976). Educational organizations as loosely coupled systems. In: Administrative Science Quarterly, 21(1), s. 1-19.

Wright, S. \& Ørberg, J. W. (2008). Autonomy and control: Danish university reform in the context of modern governance. In: Learning and Teaching, 1(1), s. 27-57. 